WAHANA

AKUNTANSI

Jumal Ilmiah
JURNAL ILMIAH WAHANA AKUNTANSI

Vol 13 (1) 2018, 1-12

http:/journal.unj.ac.id/unj/index.php/wahana-akuntansi

\title{
DETERMINASI HARGA SAHAM SYARIAH MELALUI ANALISIS TERHADAP FAKTOR FUNDAMENTAL DAN MAKRO EKONOMI
}

Taufiq Akbar*

IKPIA Perbanas

\section{Article Info}

Keywords:

Internal and external factor, Investment instrument, Sharia share.

\begin{abstract}
In the globalization era, Investment becomes something that should be prepared to face the future. Investment instruments in Indonesia were initially conventional. With its predominantly Muslim population, Indonesia must have investment instruments in accordance to sharia principles. In line with the demands of globalization, sharia investment instruments also developed including investment instruments in Indonesia such as sharia-based investment. Sharia stocks in Indonesia show growth. It can be swon bythe sharia stock market capitalization that continues to increase throughout the year. But behind it, there are many things that should be observed. Such as the fundamental factors of the company and what macroeconomic factors affect the growth rate of Sharia stocks. This study aims to analyze and obtain empirical evidence about the influence of fundamental factors and macroeconomic factors on Islamic stocks listed in the Jakarta Islamic Index. Sample is chosen by using purposive sampling method. Companies that become sample as many as 22 companies listed in JII in the second quarter period 2015 until second quarter of 2016. The regretion analysis is used and the hypothesis is tested by t-test, f-test and r-square. The results show partially only debt to equity ratio that significantly influence the stock price, while return on assets, inflation and Bank Indonesia interest rates has no effect on stock prices. Simultaneously all variables affect the stock price. The proportion of independent variables influence on the stock price is $48.5 \%$, while $51.5 \%$ is influenced by other variables that not examined in this research. So, the investor in JII should be concern with fundamental factor of company's share stock especially of debt to equity ratio.
\end{abstract}

\begin{abstract}
Abstrak
Di era globalisasi, Investasi menjadi sesuatu yang harus dipersiapkan untuk menghadapi masa depan. Instrumen investasi di Indonesia pada mulanya adalah konvensional. Dengan penduduknya yang mayoritas Muslim, Indonesia harus memiliki instrumen investasi sesuai dengan prinsip-prinsip syariah. Sejalan dengan tuntutan globalisasi, instrumen investasi syariah juga dikembangkan termasuk instrumen investasi di Indonesia seperti investasi berbasis syariah. Saham-saham syariah di Indonesia menunjukkan pertumbuhan. Hal ini dapat terjadi karena kapitalisasi pasar saham syariah yang terus meningkat sepanjang tahun. Namun dibalik itu, ada banyak hal yang patut dicermati. Seperti faktor fundamental perusahaan dan faktor makroekonomi apa yang mempengaruhi laju pertumbuhan saham syariah. Penelitian ini bertujuan untuk menganalisis dan memperoleh bukti empiris tentang pengaruh faktor fundamental dan faktor makroekonomi terhadap saham syariah yang terdaftar di Jakarta Islamic Index. Sampel dipilih dengan menggunakan metode purposive sampling. Perusahaan yang menjadi sampel sebanyak 22 perusahaan yang terdaftar di JII pada periode kuartal II 2015 hingga kuartal II 2016. Analisis regresi digunakan dan hipotesis diuji dengan uji t, uji-f dan r-square. Hasilnya menunjukkan secara parsial hanya rasio debt to equity yang berpengaruh signifikan terhadap harga saham, sedangkan return on asset, inflasi dan suku bunga Bank Indonesia tidak berpengaruh pada harga saham. Secara bersamaan semua variabel mempengaruhi harga saham. Proporsi variabel indepen berpengaruh terhadap harga saham adalah $48,5 \%$, sedangkan $51,5 \%$ dipengaruhi oleh variabel lain yang tidak diteliti dalam penelitian ini. Jadi, investor di JII harus memperhatikan faktor fundamental saham perusahaan terutama dari rasio utang terhadap ekuitas.
\end{abstract}

\section{How to Cite:}

Akbar, Taufiq dan Adam Afiezan. (2018). Determinasi Harga Saham Syariah Melalui Analisis Terhadap faktor Fundamental dan Makro Ekonomi. Jurnal Ilmiah Wahana Akuntansi, 13(1), 1-12. https://doi.org/https://doi.org/10.21009/wahana.013.1.1
*Corresponding Author:

Taufiq Akbar (taufiq.akbar@perbanas.id) 


\section{PENDAHULUAN}

Era globalisasi membentuk prilaku yang berbeda bagi manusia dalam melaksanakan kegiatan. Salah satu bentuk kemajuan dari era globalisasi adalah cara manusia melaksanakan investasi. Awalnya investasi cenderung dilakukan pada sektor riil seperti membeli tanah dan logam mulia, namun sekarang ada alternatif lain dalam berinvestasi yaitu melalui Pasar Modal. Bagi Investor pasar modal merupakan sarana untuk menanamkan modalnya pada surat berharga (Luhukay et all., 2016).

Indonesia sebagai negara yang pasar keuangannya tengah berkembang, pasar modal telah menjadi bagian penting dalam perekonomian, baik sebagai tempat penghimpun dana ataupun sebagai tempat berinvestasi. Pasar modal juga dapat dijadikan indikator stabilitas makroekonomi suatu negara.

Sebagai negara yang memiliki penduduk manyoritas beragama islam, Indonesia berkewajiban untuk memenuhi kebutuhan penduduknya. Dalam hal aktivitas Investasi, masyarakat muslim seharusnya tidak melakukan investasi yang bertentangan dengan

prinsip syariah. Oleh karena itu, Indonesia melalui Bapepam-LK telah menerbitkan paket regulasi pasar modal syariah pada tahun 2006 dan daftar efek syariah (DES) pada tahun 2007

(www.ojk.go.id). Dengan adanya DES maka masyarakat akan lebih mudak mengetahui saham mana yang telah memenuhi unsur syariah.

Dengan diluncurkannya Jakarta Islamic Index (JII) pada tahun 2000 serta sistem online trading syariah pada tahun 2011 berdampak pada meningkatnya perdagangan saham syariah di Indonesia. Jumlah saham yang masuk ke kategori syariah terus mengalami peningkatan, Namun sejak tahun 2012 sampai dengan tahun 2016 saham yang termasuk kategori syariah menunjukkan tren mendatar yaitu berada pada kisaran 304 sampai dengan 306 saham sebagaimana terlihat dalam Gambar 1 di bawah ini.

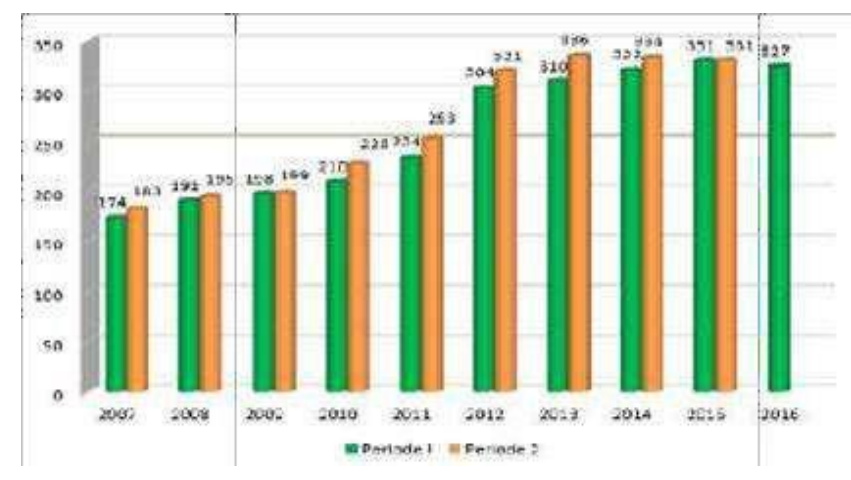

Gambar 1

\section{Perkembangan Saham Syariah}

Sumber: http://www.ojk.go.id

Gambar 1 di atas mengindikasikan bahwa keberadaan saham syariah sangat diminati oleh para investor. Sedangkan nilai kapitalisasi saham syariah yang ditunjukkan oleh JII mengalami fluktuasi. Kapitalisasi Pasar Saham Syariah JII terdapat pada Gambar 2.

Pada tahun 2007 tingkat kapitalisasi saham syariah mencapai 1,105,897.25 dan pada tahun 2008 sempat menurun menjadi Rp428.525,74. Dari tahun 2008 sampai dengan tahun 2011 kapitalisasi saham syariah terus meningkat sampai akhirnya pada tahun 2012 sempat terjadi penurunan. Namun, sebagaimana ditunjukkan oleh Gambar 2, nilai kapitalisasi saham syariah kembali menunjukkan tren kenaikan secara positif mulai tahun 2013 
hingga 2015. Ini menunjukkan bahwa kinerja saham pada JII mengalami peningkatan yang cukup baik.

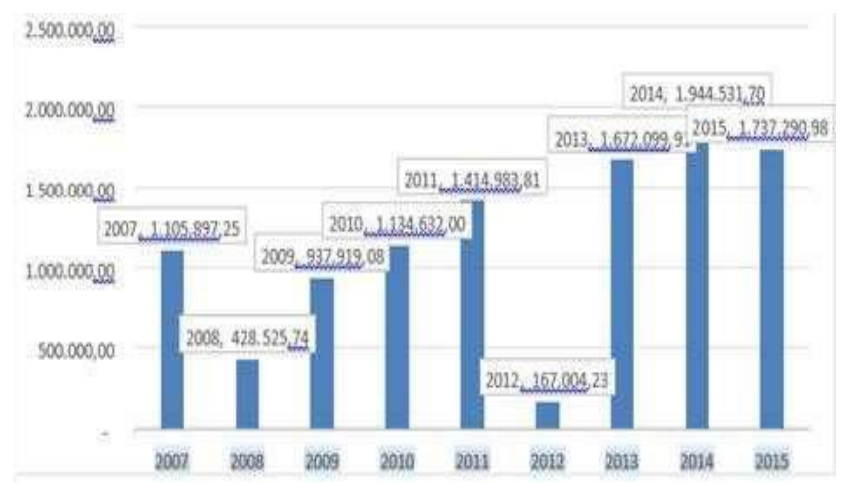

Gambar 2

\section{Kapitalisasi Pasar Saham Syariah JII} (dalam Milyar Rupiah)

Sumber: http://www.ojk.go.id

Seperti halnya pergerakan harga saham konvensional, harga saham syariah juga tidak jauh berbeda (Syafrida et all., 2014). Hal ini juga dibuktikan dengan hasil penelitian yang menunjukkan bahwa tidak adanya perbedaan yang signifikan antara kinerja saham konvesional dan saham sayariah (Setiawan dan Oktariza, 2013). Harga saham dapat dipengaruhi berbagai macam faktor baik dari sisi internal perusahaan seperti faktor fundamental maupun eksternal perusahaan seperti faktor makro ekonomi perusahaan. Beberapa penelitian telah dilakukan berkaitan dengan hal tersebut, dari sisi faktor fundamental ditemukan hasil bahwa Return on Asset (ROA) dan Debt to Equity Ratio (DER) berpengaruh terhadap harga saham (Pandansari, 2012). Namun (Raharjo dan Muid, 2013) mendapatkan hasil yang berbeda dimana kedua variabel tersebut tidak mempengaruhi harga saham.

Penelitian mengenai faktor makro ekonomi terhadap perubahan harga saham seperti yang dilakukan (Pasaribu dan Firdaus, 2013) mendapatkan hasil bahwa inflasi dan tingkat suku bunga mempengaruhi harga saham syariah secara berlawanan arah. Sementara penelitian yang dilakukan oleh (Mulyani, 2014) mendapatkan hasil bahwa inflasi berpengaruh positif terhadap harga saham.

Masih ditemukannya ketidakkonsistenan hasil penelitian terdahulu membuat peneliti tertarik untuk melakukan penelitian mengenai pengaruh variabel fundamental dan variabel makro ekonomi terhadap harga saham syariah yang terdaftar pada Jakarta Islamic Indeks.

\section{Perumusan Masalah}

Dikarenakan saham merupakan instrument investasi yang memberikan return yang tinggi, namun saham juga berisiko maka diperlukan pengetahuan mengenai faktor apa saja yang mempengaruhi pergerakan harga saham. Selain hal tersebut, hal yang menarik untuk dikaji bahwasanya terdapat ketidakkonsistenan hasil penelitian terdahulu mengenai pengaruh variabel fundamental dan faktor makro ekonomi terhadap harga saham sebagaimana yang dijelaskan dalam latar belakang di atas.

Penelitian difokuskan pada saham syariah, dengan asumsi mayoritas penduduk Indonesia beragama muslim yang tidak menutup kemungkinan akan berinvestasi pada saham syariah. Oleh karena itu, informasi mengenai investasi saham syariah sangat diperlukan, terutama informasi yang berkaitan dengan pengambilan keputusan investasi saham. Berdasarkan rumusan masalah tersebut 
maka dibentuklah pertanyaan penelitian sebagai berikut:

1. Apakah variabel fundamental seperti Return on Asset (ROA) dan Debt to Equity Ratio (DER) berpengaruh terhadap harga saham syariah yang terdaftar di JII?

2. Apakah variabel makro ekonomi seperti inflasi dan tingkat suku bunga

berpengaruh terhadap harga saham syariah yang terdaftar di JII.?

\section{TUJUAN PENELITIAN}

Tujuan penelitian ini adalah menyediakan informasi kepada investor tentang faktor fundamental perusahaan dan faktor makro ekonomi yang mempengaruhi harga saham syariah di Indonesia. Oleh karena itu secara spesifik dapat dirumuskan bahwa tujuan penelitian adalah untuk menganalisis dan mendapatkan bukti empiris mengenai:

1. Pengaruh variabel fundamental seperti Return on Asset (ROA) dan Debt to Equity Ratio (DER) terhadap harga saham syariah yang terdaftar di JII.

2. Pengaruh varibel makro ekonomi seperti inflasi dan tingkat suku bunga terhadap harga saham syariah yang terdaftar di JII.

\section{KAJIAN PUSTAKA, KERANGKA PEMIKIRAN, DAN HIPOTESIS Pasar}

\section{Modal Syariah di Indonesia}

Pasar modal syariah merupakan kegiatan pasar modal yang memiliki karakteristik khusus dimana memperhatikan pemenuhan prinsip syariah dalam menciptakan produk, membuat kontrak dalam penerbitan efek syariah, melakukan transaksi perdagangan, serta melakukan aktivitas pasar modal lainnya. Prinsip syariah yang harus dipenuhi antara lain terhindarnya aktivitas pasar modal syariah dari unsur perjudian (maysir), ketidakpastian

(gharar), sistem bunga (riba), dan ketidakadilan.

Pasar modal syariah di Indonesia telah berkembang sejak tahun 1997 dimana ditandai dengan diluncurkannya reksa dana syariah. Sejak saat itu, pasar modal syariah Indonesia terus tumbuh dan berkembang yang ditandai dengan semakin banyaknya produk syariah, diterbitkannya regulasi terkait pasar modal syariah dan semakin bertambahnya masyarakat yang mengenal dan peduli pasar modal syariah. Perkembangan pasar modal syariah tersebut patut diapresiasi. Namun demikian, mengingat bahwa market share produk syariah di pasar modal yang masih relatif kecil, maka dari itu diperlukan suatu strategi untuk meningkatkan market share produk syariah. Salah satunya adalah peningkatan pengetahun investasi di saham syariah.

Perubahan harga suatu saham dapat dipengaruhi beberapa faktor, diantaranya faktor internal seperti fundameltal perusahaan dan faktor eksternal seperti faktor makro ekonomi suatu perusahaan. Faktor fundamental dapat menunjukkan kinerja keuangan perusahaan dan dapat juga menunjukkan kinerja saham suatu perusahaan. Sementara faktor makro ekonomi dapat mempengaruhi kinerja perusahaan tersebut. Kinerja saham syariah di Indonesia akan dianalisis dengan menggunakan kedua faktor tersebut. 


\section{Pengaruh ROA Terhadap Harga Saham Syariah}

Menurut Mardiyanto (2009), Return on Asset (ROA) adalah rasio yang digunakan untuk mengukur kemampuan manajemen dalam memperoleh keuntungan secara keseluruhan. Semakin besar ROA maka semakin besar pula tingkat keuntungan yang dicapai oleh perusahaan dari penggunaan aktiva. Dengan kata lain, semakin tinggi ROA, maka semakin baik kinerja perusahaan. Kinerja perusahaan yang baik akan menjadi daya tarik perusahaan terhadap investor. Hal ini membuat permintaan akan saham meningkat sehingga harganya pun akan naik. Sama halnya dengan perusahaan yang sahamnya masuk dalam kriteria saham syariah. Kinerja ROA Perusahaan yang bagus juga mempengaruhi harga saham syariah. Hal ini sejalan dengan hasil penelitian (Watung dan Ilat, 2016) yang menemukan bahwa ROA berpengaruh terhadap harga saham syariah.

Berdasarkan penjelasan tersebut maka dibentuklah hipotesis sebagai berikut:

$\mathrm{H}_{1}$ : Return on Asset berpengaruh terhadap harga saham.

\section{Pengaruh DER Terhadap Saham Syariah}

Menurut (Kasmir, 2010), Debt to Equity Ratio (DER) merupakan rasio yang digunakan untuk menilai hutang dan ekuitas. Rasio ini dicari dengan cara membandingkan antara seluruh hutang dengan seluruh ekuitas. DER adalah rasio yang menunjukkan presentase penyediaan dana oleh pemegang saham terhadap pemberi pinjaman. Semakin tinggi rasio ini, menunjukkan semakin rendah pendanaan yang disediakan oleh pemegang saham. Sebaliknya, semakin rendah rasio DER, maka semakin baik kemampuan perusahaan dalam membayar kewajiban jangka panjangnya. Informasi rasio DER yang rendah, akan diterima pasar sebagai sinyal baik yang akan memberikan masukan positif bagi investor dalam pengambilan keputusan membeli saham. Hal ini akan membuat permintaan saham meningkat dan harga saham pun akan naik. Sama halnya dengan perusahaan yang sahamnya masuk dalam kriteria saham syariah, kinerja DER Perusahaan yang bagus juga mempengaruhi harga saham syariah. Hal ini sejalan dengan hasil penelitian Anugrah dan Syaichu (2017) yang menemukan bahwa DER berpengaruh secara signifikan terhadap harga saham syariah.

Berdasarkan penjelasan tersebut maka dibentuklah hipotesis sebagai berikut:

$\mathrm{H}_{2}$ : Debt to Equity Ratio berpengaruh terhadap harga saham.

\section{Pengaruh Inflasi Terhadap Harga Saham Syariah}

Salah satu indikator ketidakstabilan perekonomian suatu negara dapat dilihat dari peningkatan inflasi. Umumnya peningkatan inflasi ditandai dengan harga kebutuhan pokok yang meningkat. Dengan adanya peningkatan biaya kebutuhan pokok, maka semakin kecil peluang individu dalam melakukan investasi termasuk investasi saham di pasar modal. Penurunan investasi saham dapat menyebabkan menurunnya harga saham dikarenakan tingginya penawaran sementara tidak adanya permintaan. Sama halnya dengan investasi pada 
saham syariah, tingkat infkasi juga mempengaruhi harga saham syariah. Hal ini sejalan dengan hasil penelitian (Pasaribu dan Firdaus, 2013) dimana peningkatan inflasi berdampak pada menurunnya harga saham.

Berdasarkan penjelasan tersebut maka dibentuklah hipotesis sebagai berikut:

$\mathrm{H}_{3}$ : Inflasi berpengaruh terhadap harga saham.

\section{Pengaruh Tingkat Suku Bunga Terhadap Harga Saham Syariah}

Tingkat suku bunga bank yang tinggi membuat individu memilih investasi di bank dari pada di pasar modal. Hal ini dikarena investasi di bank memberikan hasil yang lebih aman dengan tingkat suku bunga yang tinggi. Sementara itu, penurunan investasi di pasar modal dapat menyebabkan menurunnya harga saham dikarenakan tingginya penawaran sementara tidak adanya permintaan. Sama halnya dengan investasi pada saham syariah, tingkat suku bunga bank juga mempengaruhi harga saham syariah. Hal ini sejalan dengan hasil penelitian (Pasaribu dan Firdaus, 2013) dimana peningkatan suku bunga bank mempengaruhi harga saham.

Berdasarkan penjelasan tersebut maka dibentuklah hipotesis sebagai berikut:

$\mathrm{H}_{4}$ : Tingkat suku bunga berpengaruh terhadap harga saham.

\section{OBJEK DAN METODOLOGI PENELITIAN}

\section{Tahapan Penelitian}

Jenis penelitian yang dilakukan adalah pure research dimana bertujuan untuk memverifikasi diterimanya teori yang sudah ada dan mengetahui lebih jauh tentang sebuah konsep (Abdillah dan Hartono, 2015). Pendekatan yang digunakan adalah pendekatan kuantitatif dengan meneliti populasi dan sample tertentu dengan analisis bersifat kuantitatif/statistik yang ditujukan untuk menguji hipotesis yang telah ditetapkan (Sugiyono, 2012).

\section{Jenis Data, Tempat dan Waktu Penelitian}

Data yang digunakan dalam penelitian ini adalah data sekunder. Data sekunder adalah data yang diperoleh dari sumber yang telah ada. Data sekunder tersebut dapat berupa laporan, publikasi, buku dan lain sebagainya. Data sekunder pada penelitian berupa:

1. Data Harga Saham Syariah pada kuartal ke 2 tahun 2015 sampai kuartal ke 2 tahun 2016 yang termasuk dalam Jakarta Islamic Indeks pada saham yang terdaftar di Bursa Efek Indonesia. Data didapat dari situs resmi Bursa Efek Indonesia (www.idx.co.id).

2. Data laporan keuangan pada kuartal ke 2 tahun 2015 sampai kuartal ke 2 tahun 2016 yang didapat dari situs resmi Bursa Efek Indonesia (www.idx.co.id).

3. Data Inflasi di Indonesia pada kuartal ke 2 tahun 2015 sampai kuartal ke 2 tahun 2016 yang terdapat pada indikator ekonomi dari situs resmi Badan Pusat Statistik (www.bps.go.id) dan data Tingkat Suku Bunga Jumlah Uang Beredar di Indoneisa pada akhir tahun selama tahun 2010 - 2015 yang diperoleh dari data statistik Bank Indonesia (www.bi.go.id). 


\section{Perubahan yang Diamati}

Pengamatan penelitian ditujukan pada seperangkat variabel bebas yaitu faktor makro ekonomi terhadap variabel terikat yaitu perubahan harga saham syariah yang termasuk dalam Jakarta Islamic Indeks. Tabel 1 di bawah ini menyajikan tentang definisi variabel yang diamati.

\section{Tabel 1}

\section{Definisi Variabel Yang Diamati}

\begin{tabular}{|c|c|c|c|c|}
\hline Variabel & Konsen Variabel & \multicolumn{2}{|l|}{ Indikatox } & Skala \\
\hline Harga Saham & $\begin{array}{l}\text { Harga yang tetbentuk } \\
\text { akibat penatiaran dan } \\
\text { permintaan saham dard } \\
\text { peniual dan pembeli }\end{array}$ & \multicolumn{2}{|l|}{$\begin{array}{l}\text { Nilai Harea saham dalam III } \\
\text { Dada periode pengamatan } \\
\text { penelitian }\end{array}$} & Nomina! \\
\hline $\begin{array}{l}\text { Retum on } \\
\text { Assets (ROA) }\end{array}$ & $\begin{array}{c}\text { Rasio yang } \\
\text { meruuniukkan } \\
\text { kemampuan dari modal } \\
\text { yang dinvestasikan } \\
\text { dalam keseluruhan } \\
\text { aktiva dalam } \\
\text { menghasilkan laba }\end{array}$ & 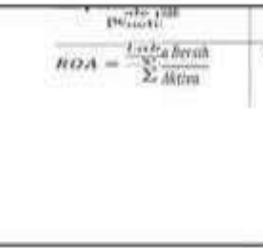 & $\mathrm{kan}$ & Rasie \\
\hline $\begin{array}{c}\text { Debt to } \\
\text { Equity Ratio } \\
\text { (DER) }\end{array}$ & $\begin{array}{l}\text { Rasio yang menugiukan } \\
\text { presentase penvediaan } \\
\text { dana gleh pemegang } \\
\text { saham tethadap pemberi } \\
\text { pinizman }\end{array}$ & 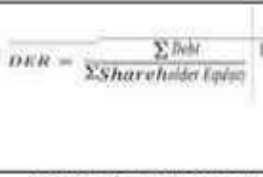 & la & Rasio \\
\hline Inflas & $\begin{array}{l}\text { Inflasi dapat diaktan } \\
\text { sebagai keaikan harga } \\
\text { secara tenus menens? }\end{array}$ & $\begin{array}{l}\text { Nilai Inflasi pada periods } \\
\text { pengamatan penelitian }\end{array}$ & & Nominal \\
\hline $\begin{array}{l}\text { Tingkat Suku } \\
\text { Bunga }\end{array}$ & $\begin{array}{l}\text { Suku bunga kcbijakan } \\
\text { yang mencerminkan } \\
\text { sikan kebijakan moneter } \\
\text { yang ditctapkan Bank } \\
\text { Indonesia dan } \\
\text { drumumkan ke Publik }\end{array}$ & $\begin{array}{l}\text { Nilai BI rate pada periode } \\
\text { pengamatan penelitian }\end{array}$ & & Nominal \\
\hline
\end{tabular}

Sumber: Data diolah penulis, Tahun 2018

\section{Teknik Pengumpulan Data}

Populasi adalah objek penelitian yang memiliki kualitas dan karakteristik tertentu yang ditetapkan oleh peneliti untuk dipelajari dan kemudian ditarik kesimpulan (Sugiyono, 2012). Populasi dalam penelitian ini adalah seluruh saham syariah yang masuk ke dalam Jakarta Islamic Indeks di Bursa Efek Indonesia. Sempel dipilih dengan menggunakan tehnik purposive sampling yaitu pemilihan sample berdasarkan suatu kriteria tertentu (Jogiyanto,
2010).

Kriteria yang ditentukan dalam pemilihan sampel adalah:

1. Saham yang termasuk dalam Jakarta Islamic Indeks selama periode penelitian (kuartal ke 2 tahun 2015 sampai kuartal ke 2 tahun 2016).

2. Data Makro Ekonomi sebagai variabel Independen.

3. Data tersedia untuk dianalisis.

\section{Analisis Data}

Pada penelitian analisis data dilakukan dengan terlebih dahulu melakukan pengujian asumsi klasik dengan melakukan uji normalitas, multikolinearitas, heterokedastisitas dan autokorelasi. Setelah data dari variable yang diteliti lolos uji asumsi klasik barulah dilakukan pengujian hipotesis dengan melakukan Uji t, Uji F, dan koefisien determinasi.

\section{PEMBAHASAN}

\section{Uji Normalitas}

Uji normalitas dilakukan untuk melihat apakah variabel independen dan dependen mempunyai distribusi normal atau tidak. Pengujian normalitas data pada penelitian ini menggunakan metode grafik normal P-Plot dari Standardized residual cumulative probability, dengan identifikasi apabila sebarannya berada disekitar garis normal, maka dapat disimpulkan bahwa variabel independen dan dependen berdistribusi normal. Hasil dari grafik normal PPlot dapat dilihat pada Gambar 3.

Pada grafik P-Plot di atas, dapat diketahui bahwa titik-titik menyebar pada garis diagonal. 
Grafik tersebut menunjukan bahwa model regresi layak dipakai karena memenuhi asumsi normalitas atau dengan kata lain bahwa model regresi dapat dilanjutkan.

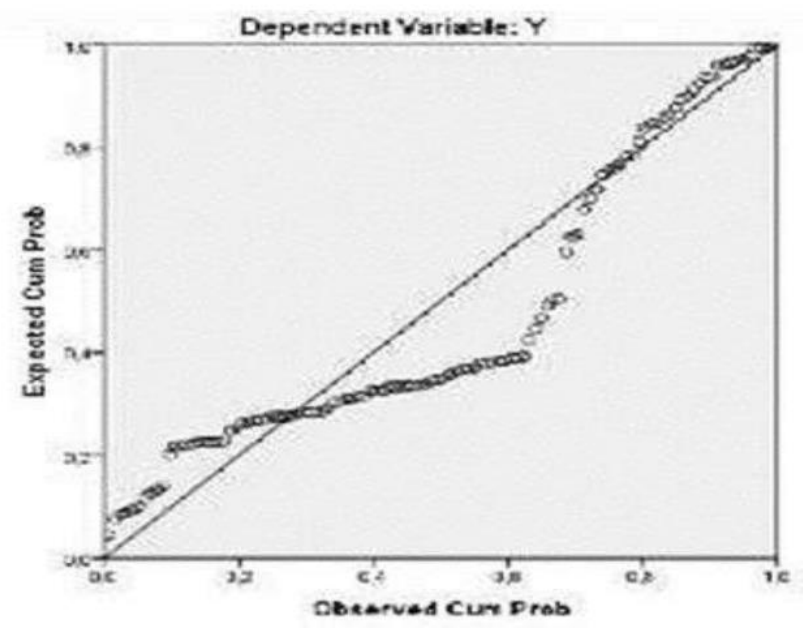

Gambar 4

Hasil Uji Normalitas dengan P-Plot

Sumber: Data diolah penulis, Tahun 2018

\section{Uji Multikolinearitas}

Uji Multiolinearitas bertujuan untuk menguji apakan dalam model regresi ditemukan adanya korelasi antar variabel bebas. Model regresi yang baik seharusnya antar variabel bebas tidak terjadi korelasi. Multikolinearitas dapat dilihat dari nilai tolerance dan Variance Inflation Factor (VIF). Jika nilai VIF lebih besar dari 10 dan nilai tolerance kurang dari 0.1 maka akan terjadi multikolinearitas dan model regresi layak untuk dipakai. Hasil perhitungan tolerance dan VIF dapat dilihat pada Tabel 2.

Hasil pada Tabel 2 menunjukan bahwa semua variabel bebas mempunyai nilai tolerance diatas 0.1 dan nilai VIF berada dibawah angka 10. Hal ini menunjukkan bahwa antar variabel bebas yang digunakan pada penelitian ini tidak menunjukan adanya multikolineraitas sehingga model regresi ini layak untuk pengujian hipotesis.

Tabel 2

Hasil Pengujian Multikolinearitas

\begin{tabular}{|c|c|c|c|}
\hline & \multirow[b]{2}{*}{ Model } & \multicolumn{2}{|c|}{ Collinearity Statistics } \\
\hline & & Tolerance & VIF \\
\hline \multirow[t]{5}{*}{1} & (Constant) & & \\
\hline & $\times 1$ & 982 & 1,018 \\
\hline & $\times 2$ & ,998 & 1,002 \\
\hline & $\times 3$ & ,664 & 1,505 \\
\hline & $\times 4$ & ,671 & 1,491 \\
\hline
\end{tabular}

Sumber: Data diolah penulis, Tahun 2018

\section{Uji Heterokedastisitas}

Uji heteroskedastisitas bertujuan untuk menguji apakah dalam model regresi terjadi ketidaksamaan varian dari residual satu pengamatan ke pengamatan yang lain. Untuk menguji hal ini dapat digunakan scatterplot, dimana sumbu $\mathrm{X}$ adalah nilai-nilai prediksi ZPRED $=$ Regression Standardized Predicted Value dengan sumbu Y adalah nilai ZRESID = Regression Standardized Predicted Value. Bila grafik yang diperoleh menunjukan adanya pola tertentu yang dihasilkan oleh titik-titik yang ada maka dikatakan terjadi heteroskedastisitas, namun bila tidak membentuk pola tertentu maka dikatakan tidak terjadi heteroskedastisitas. Hasil uji heteroskedastisitas dapat dilihat pada Gambar 5.

Dari hasil uji heteroskedastisitas yang disajikan pada Gambar 5 dapat dilihat bahwa titik-titik scatterplot di atas tidak membentuk pola tertentu. Hal ini menunjukan bahwa model regresi tidak terkena heteroskedastisitas. 


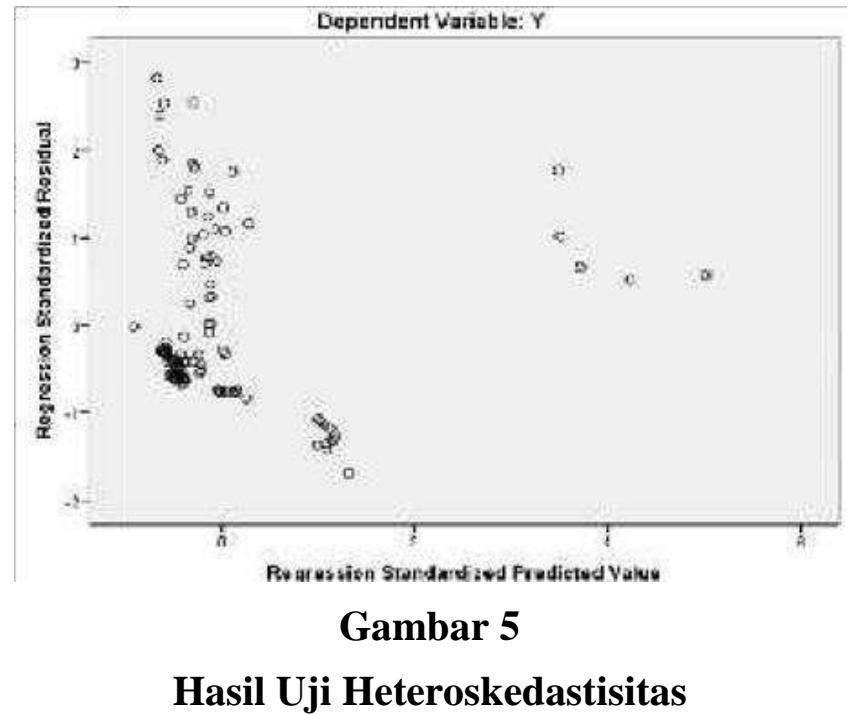

Sumber: Data diolah penulis, Tahun 2018

\section{Uji Autokorelasi}

Uji Autokorelasi bertujuan untuk menguji apakah dalam suatu model regresi linear ada korelasi antar anggota sampel yang diurutkan berdasarkan waktu. Model regresi yang baik adalah yang terbebas dari autokorelasi. Untuk menguji ada atau tidaknya korelasi dapat dilakukan melalui pengujian terhadap nilai Durbin Watson. Hasil Uji autokorelasi dapat dilihat pada Tabel 3

\section{Tabel 3}

Hasil Uji Autokorelasi

\begin{tabular}{|r|r|r|r|r|r|}
\hline Model & \multicolumn{1}{|c|}{$R$} & R Square & $\begin{array}{c}\text { Adjusted R } \\
\text { Square }\end{array}$ & $\begin{array}{c}\text { Std. Error of the } \\
\text { Estimate }\end{array}$ & Durbin-Watson \\
\hline 1 &, $710^{4}$ &, 504 &, 485 & 6722,6002 & 470 \\
\hline
\end{tabular}

Sumber: Data diolah penulis, Tahun 2018

Dari hasil uji autokorelasi di atas, menunjukan bahwa nilai Durbin-Watson adalah sebesar 0.470. Berarti, nilai Durbin-Watson berada diantara -2 dan 2 . Hasil ini menunjukan bahwa model regresi yang digunakan peneliti tidak mengalami masalah autokorelasi.

\section{Uji Hipotesis}

\section{Uji Parameter Individu (Uji t)}

Uji parameter individual digunakan untuk mengetahui seberapa jauh pengaruh dan signifikansi hubungan antara variabel independen dengan variabel dependen. Hasil uji statistik t menunjukan seberapa jauh pengaruh satu variabel independen secara individual dalam menerangkan variasi variabel dependen dan digunakan untuk mengetahui ada atau tidaknya pengaruh masing-masing variabel independen secara individual terhadap variabel dependen yang diuji pada tingkat signifikansi 0,05. Hasil uji parameter individual dari penelitian ini disajikan pada Tabel 4 berikut ini.

\section{Tabel 4}

\section{Hasil Uji Parameter Individual}

\begin{tabular}{|r|r|r|r|r|r|}
\hline Variabel & t hitung & t table & Pengaruh & \multicolumn{1}{c|}{ Sig. } & Signifikansi \\
\hline $\mathbf{X}_{1}$ &,- 417 & 1,983 & Tidak &, 678 & Tidak \\
$\mathbf{X}_{2}$ & 10,289 & 1,983 & Berpengaruh &, 000 & Signifikan \\
$\mathbf{X}_{3}$ &, 278 & 1,983 & Tidak &, 782 & Tidak \\
$\mathbf{X}_{4}$ &,- 081 & 1,983 & Tidak &, 936 & Tidak \\
\hline
\end{tabular}

Sumber: Data diolah penulis, Tahun 2018

Dari Tabel 4 dapat dilihat bahwa variable $\mathrm{X}_{2}$ (debt to equity ratio) yang memiliki nilai $\mathrm{t}$ hitung lebih besar dari pada nilai t tabel. Maka dari itu dapat kita simpulkan bahwa secara individu hanya DER yang mempengaruhi pergerakan harga saham. Selain itu dapat dilihal bahwa pengaruh DER terhadap harga saham memiliki tingkat keyakinan yang tinggi, hal ini ditunjukkan dengan nilai sig dari DER lebih kecil dari 0,05 .

\section{Uji Simultan (Uji F)}

Uji pengaruh simultan digunakan untuk menunjukan bahwa variabel independen secara 
bersama-sama mempengaruhi variabel dependen. Hasil uji $\mathrm{F}$ dalam penelitian dapat dilihat pada Tabel 5

\section{Tabel 5}

\section{Hasil Uji Simultan (Uji F)}

\begin{tabular}{|r|r|c|c|r|}
\hline$f$ hitung & $f$ table & Pengaruh & Sig. & Signifikansi \\
\hline 26,680 & 1,35 & Berpengaruh &, 000 & Signifikan \\
\hline
\end{tabular}

Sumber: Data diolah penulis, Tahun 2018

Dari Tabel di atas dapat disimpulkan bahwa F-hitung lebih besar dari F-tabel. Sementara untuk tingkat signifikansinya uji $\mathrm{F}$ memiliki tingkat signifikansi 0.000 atau lebih kecil dari 0.050. Berdasarkan hasil tersebut, dapat dikatakan bahwa return on assets, debt to equity ratio, Inflasi dan tingkat suku bunga berpengaruh signifikan secara simultan terhadap harga saham.

\section{Uji Koefisien Determinasi}

Uji koefisien determinasi digunakan untuk mengukur seberapa besar presentase variasi variabel independen pada model regresi linier berganda terhadap variabel dependen. Nilai koefisien determinasi adalah antara nol dan satu. Hasil perhitungan 2 koefisien determinasi (R) dalam penelitian ini disajikan dalam Tabel 6.

\section{Tabel 6}

\section{Hasil Uji Koefisien Determinasi}

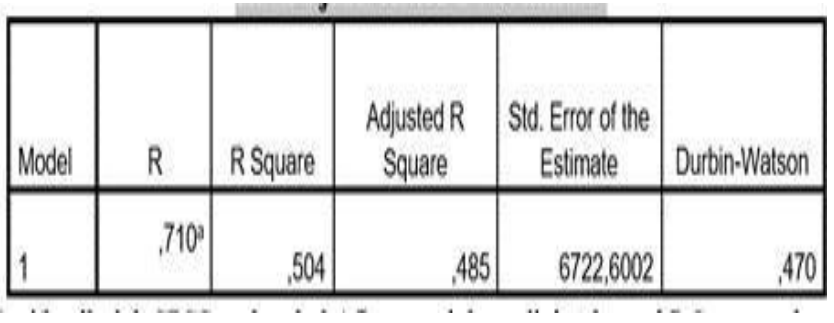

Sumber: Data diolah penulis, Tahun 2018
Dari hasil olah SPSS yang disajikan pada Tabel 6 di atas menunjukan nilai Adjusted $R$ Square sebesar 0,485 atau 48,5\%. Artinya sebanyak $48,5 \%$ variasi model dapat dijelaskan dalam variasi dari keempat variabel yaitu return on assets, debt to equity ratio, Inflasi dan tingkat suku bunga. Sedangkan sisanya 51,5\% dijelaskan oleh variabel-variabel lain yang tidak diajukan dalam penelitian.

\section{KESIMPULAN DAN SARAN}

\section{Kesimpulan}

Berdasarkan analisis yang dijelaskan sebelumnya dari empat variabel independent yang diteliti hanya variabel debt to equity ratio yang berpengaruh secara signifikan terhadap harga saham syariah yang terdaftar di Jakarta Islamic Indeks periode kuartal ke dua tahun 2015 sampai kuartal ke dua tahun 2016. Hal ini memperkuat hasil dari beberapa peneliti sebelumnya seperti yang dilakukan oleh (Stella, 2009), (Buigut et all., 2013), (Ratih et all.,

2013), (Nahoji et all., 2014), dan (Mussalamah dan Isa, 2015) mendapatkan hasil bahwa debt to equity ratio berpengaruh secara signifikan terhadap hargas saham.

Penelitian ini membuktikan bahwa fariabel fundamental perusahaan lebih memiliki pengaruh terhadap harga saham dari pada fariabel makro ekonomi. Dimana hasil studi memperlihatkan hanya variabel Debt to Equity berpengaruh secara signifikan terhadap harga saham syariah sementara faktor lain seperti Return On Asset, inflasi, dan tingkat suku bunga tidak berpengaruh terhadap harga saham. Faktor makro ekonomi tidak memiliki pengaruh 
mungkin disebabkan karena inflasi dan tingkat suku bunga menunjukkan tren mendatar selama periode penelitian dan tidak terjadi fluktuasi yang signifikan. Proporsi pengaruh varaibel indepen yang diteliti terhadap harga saham sebesar 48,5\%, sedangkan sebesar $51,5 \%$ dipengaruhi oleh variabel independen lain yang tidak diteliti dalam penelitian ini.

\section{Implikasi}

Dari hasil penelitian yang didapatkan diharapkan investor lebih memperhatikan faktor fundamental perusahaan terutama varibel debt to equity ratio. Hal ini disebabkan karena debt to equity ratio memiliki pengaruh yang signifikan terhadap harga saham. Namun bukan berarti faktor makro ekonomi merupakan faktor yang dapat dibaikan, tidak berpengaruhnya faktor makro ekonomi disebabkan karena pada periode penelitian tingkat inflasi dan suku bunga bank tidak menunjukkan tren yang fluktuatif atau tidak menunjukkan keadaan yang menghawatirkan.

\section{Keterbatasan}

Peneliti tidak dapat membuktikan bahwa faktor makro ekonomi memiliki pengaruh terhadap harga saham. Hal ini disebabkan pada periode penelitian inflasi menunjukkan tren yang baik. Untuk pembuktian pengaruh variabel makro ekonomi terhadap harga saham mungkin peneliti selanjutnya dapat menggunakan periode penelitian dimana terjadi adanya tren yang fluktuatif pada faktor inflasi dan tingkat suku bunga. Hasil penelitian ini juga menunjukkan proporsi pengaruh varaibel indepen yang diteliti terhadap harga saham sebesar $48,5 \%$, berarti terdapat variabel lain yang harus diteliti yang memberikan dampak yang lebih besar terhadap harga saham sebesar 51,5\%.

\section{DAFTAR PUSTAKA}

Abdillah, W., dan Hartono, J. 2015. Partial least square (PLS): Alternatif structural equation modelling (SEM) dalam penelitian bisnis. Yogyakarta: Penerbit Andi Offset.

Anugrah, A., dan Syaichu, M. 2017. Analisis pengaruh return on equity, debt to equity ratio, current ratio, dan price to book value terhadap return saham syariah (Studi kasus pada perusahaan yang terdaftar dalam Jakarta Islamic Index periode 2011-2015), Diponegoro journal of manajemen: 1-12.

Buigut, K., Soi, N., Koskei, I., dan Kibet, J. 2013. The effect of capital structure on share price on list firms in Kenya. A case of energy listed firms, Europian journal of business and management: 29-34.

Jogiyanto. 2010. Metodologi Penelitian Bisnis:

Salah Kaprah dan PengalamanPengalaman. Yogyakarta: BPFEYOGYAKARTA.

Kasmir. 2010. Analisis laporan keuangan. Jakarta: Raja Grafindo Persada. Keputusan Ketua Badan Pengawas Pasar Modal dan Lembaga Keuangan. No. KEP $-130 / \mathrm{BL} / 2006$.

Luhukay, R., Mangantar, M., dan Baramuli, D. 2016. Analisis Pengaruh Kinerja Keuangan terhadap Harga Saham pada Perusahaan Rokok yang Terdaftar di Bursa Efek Indonesia, Jurnal EMBA: 501 -510 .

Mardiyanto, H. 2009. Intisari manajemen keuangan. Jakarta: Grasindo. 
Mulyani, N. 2014. Analisis Pengaruh Inflasi, Suku Bunga, Nilai Tukar Rupiah, dan Produk Domestik Bruto Terhadap Jakarta Islamic Indeks, Jurnal Bisnis dan Manajemen Eksekutif.

Mussalamah, A. D. M., dan Isa, M. 2015. Pengaruh earning per share (EPS), debt to equity ratio (DER) dan return on equity (ROE) terhadap harga saham (Studi empiris pada perusahaan manufaktur yang terdaftar di bursa efek Indonesia tahun 2007-2011), BENEFIT jurnal manajemen dan bisnis: 189-195.

Nahoji, S. J. M., Abadi, H. R. D., dan Rafat, B. 2014. The relationship between stock price and debt ratio and capital flows with assets, Interdisciplinary journal of contemporary research in business: $34-43$.

Otoritas Jasa Keuangan (2017). Roadmap Pasar Modal Syariah. Diakses Janurai 24, 2017 dari http://www.ojk.go.id/Files/box/ roadmap-pms_2015-2019. pdf Otoritas Jasa Keuangan (2017). Statistik Saham Syariah. Diakses Januari 24, 2017 dari http://www.ojk.go.id/id/kanal/syariah/data -dan-statistik/saham-syariah/Page Statistik -Saham-Syariah-September-2016.aspx

Pandansari, F. A. 2012. Analisis faktor fundamental terhadap harga saham, Accounting analysis journal: 28-34.

Pasaribu, R. B. F., dan Firdaus, M. 2013. Analisis Variabel Makro Ekonomi Terhadap Saham Syariah Indonesia, Jurnal Ekonomi dan Bisnis: 117-128.

Raharjo, D., dan Muid, D. 2013. Analisis pengaruh factor-faktor fundamental rasio keuangan terhadap perubahan harga saham, Diponegoro journal of accounting: $1-11$.

Ratih, D., Apriatni, E. P., dan Saryadi. 2013. Pengaruh EPS, PER, DER, ROE terhadap harga saham pada perusahaan sector pertambangan yang terdaftar di Bursa Efek Indonesia (BEI) tahun 2010-2012, Diponegoro journal of social and politic: 1-12.
Setiawan, C., dan Oktariza, H. 2013. Syariah and Conventional Stocks Performance of Public Companies Listed on Indonesia Stock Exchange, Journal of Accounting, Finance and Economics: 51-64.

Stella. 2009. Pengaruh price to earning ratio, debt to equity ratio, return on asset dan price to book value terhadap harga saham, Jurnal bisnis dan akuntansi: 97-106.

Sugiyono. 2012. Metode Penelitian Kombinasi (Mixed Methods). Bandung: Alfabeta.

Syafrida, I., Aminah, I., dan Waluyo, B. 2014. Perbandingan kinerja instrumen investasi berbasis syariah dengan konvensional pada pasar modal di Indonesia, AlIqtishad: 195206.

Watung, R. W., dan Ilat, V. 2016. Pengaruh return on assets (ROA), net profit margin (NPM), dan earning per share (EPS) terhadap harga saham perusahaan perbankan di Bursa Efek Indonesia periode 2011-2015, Jurnal EMBA: 518529. 